OPEN ACCESS

Edited by:

Wanderley De Souza,

Federal University of Rio

de Janeiro, Brazil

Reviewed by:

Hugo D. Lujan,

Consejo Nacional de Investigaciones

Cientificas y Técnicas (CONICET),

Argentina

M. Guadalupe Ortega-Pierres,

Centro de Investigaciones y Estudios

Avanzados, Instituto Politécnico

Nacional de México (CINVESTAV),

Mexico

*Correspondence:

Shahram Solaymani-Mohammadi

shahram.solaymani@und.edu

orcid.org/0000-0001-9749-3830

Specialty section:

This article was submitted to

Parasite Immunology,

a section of the journal

Frontiers in Immunology

Received: 18 November 2021

Accepted: 31 January 2022

Published: 17 February 2022

Citation:

Solaymani-Mohammadi S (2022) Mucosal Defense Against Giardia at the Intestinal Epithelial Cell Interface.

Front. Immunol. 13:817468. doi: 10.3389/fimmu.2022.817468

\section{Mucosal Defense Against Giardia at the Intestinal Epithelial Cell Interface}

\author{
Shahram Solaymani-Mohammadi * \\ Laboratory of Mucosal Immunology, Department of Biomedical Sciences, School of Medicine and Health Sciences, \\ University of North Dakota, Grand Forks, ND, United States
}

Human giardiasis, caused by the protozoan parasite Giardia duodenalis (syn. Giardia lamblia, Giardia intestinalis, Lamblia intestinalis), is one of the most commonly-identified parasitic diseases worldwide. Chronic G. duodenalis infections cause a malabsorption syndrome that may lead to failure to thrive and/or stunted growth, especially in children in developing countries. Understanding the parasite/epithelial cell crosstalk at the mucosal surfaces of the small intestine during human giardiasis may provide novel insights into the mechanisms underlying the parasite-induced immunopathology and epithelial tissue damage, leading to malnutrition. Efforts to identify new targets for intervening in the development of intestinal immunopathology and the progression to malnutrition are critical. Translating these findings into a clinical setting will require analysis of these pathways in cells and tissues from humans and clinical trials could be devised to determine whether interfering with unwanted mucosal immune responses developed during human giardiasis provide better therapeutic benefits and clinical outcomes for $G$. duodenalis infections in humans.

Keywords: giardiasis, Giardia duodenalis, mucosal immunity, intestinal barrier, epithelium, antimicrobial peptides, disaccharidase deficiency

\section{INTRODUCTION}

Human giardiasis, caused by the protozoan parasite Giardia duodenalis (syn. Giardia lamblia, Giardia intestinalis, Lamblia intestinalis), is one of the most prevalent enteric parasitic protozoan infections globally, with prevalence rates ranging from $2-5 \%$ in the developed world and $20-30 \%$ in the developing countries (1-3). Infections with G. duodenalis account for more than 280 million of new cases of human giardiasis annually worldwide $(4,5)$. Epidemiological and molecular studies have classified G. duodenalis parasites into eight distinct and genetically-different parasites or "assemblages" (A-H) of which only assemblages A and B are typically identified in both humans and in other mammalian hosts, whereas assemblage E, for example, is predominantly identified in the livestock $(6,7)$. In recent years, however, assemblage $\mathrm{E}$ has also been identified to infect humans in Brazil (8, 9), Egypt (10), Australia (11), Vietnam (12) and New Zealand (13). This further indicates the potential for more widespread anthropozoonotic importance of $G$. duodenalis parasites and the roles played by numerous mammalian species in the maintenance of the parasite's life cycle. The parasite's life cycle follows a direct oral-fecal transmission route, and human infections are initiated by the ingestion of quadrinucleate cysts along with contaminated food or water (1). The ingestion of as few as 10-25 cysts would be enough to successfully colonize the small intestine (14). 
The vegetative forms of the parasite or trophozoites are binuclear pear-shaped flagellated structures with a bilateral symmetry that colonize the proximal portions of the small intestine, especially the duodenum and less commonly jejunum and the ileum (15).

Most cases of human giardiasis in immunocompetent individuals are self-limiting and and are spontaneously resolved within weeks following exposure (14). Individuals residing in hyperendemic areas for human giardiasis develop partial immunity against subsequent infections as opposed to newly arrived visitors $(16,17)$. These findings indicate the development of an effective anti-Giardia immunity sufficient for the clearance of G. duodenalis infections in humans. The majority of human giardiasis cases are asymptomatic with no signs of overt clinical profiles $(18,19)$. Human cases with asymptomatic giardiasis predominantly excrete infective cysts in the feces and play important roles in the maintenance of the parasite's life cycle (1). Nonetheless, human subjects with symptomatic giardiasis mostly shed trophozoites in feces and are commonly presented with gastrointestinal manifestations that may include abdominal cramps, flatulence, diarrhea, nausea, with a malabsorption syndrome occurring in clinical and subclinical cases and may result in failure to thrive (FTT) and/or stunted growth, especially in children (20-23). The malabsorption syndrome observed during chronic human giardiasis is characterized by a steatorrhea type diarrhea with signs of fat- (i.e., vitamins $\mathrm{A}, \mathrm{K}$ ) and water-soluble (i.e., vitamin B12) vitamins deficiency (24-29). In persistent cases of giardiasis, especially in children under the age of 5 , significant weight loss accompanied by a wasting protein-losing enteropathy are also present (30-33).

\section{GIARDIA DISRUPTS TIGHT JUNCTION PROTEINS AND MODULATES INTESTINAL BARRIER INTEGRITY}

Tight junction (TJ) proteins represent major components of the intercellular adhesion molecules and regulate the permeability of epithelial (i.e., intestine) and endothelial barrier functions [for a review see ref (34)]. These molecules are multi-protein complexes required for defining the structurally- and functionally-distinct basolateral and apical plasma membrane domains and are critical for the maintenance of the cell polarity and paracellular passage (34). The TJ proteins are not entirely impermeable yet the passive trans-epithelial passage of ions and small molecules occurs depending on molecule's size and polarity (35-37). It has been clearly established that TJ proteins play critical and non-redundant roles in multiple organs. The ZO-1 or ZO-2 deficiency was embryonically lethal in mice $(38,39)$, whereas mice deficient for claudin 1 died shortly after the birth owing to excessive dehydration of the skin (40). While mice deficient for occludin $\left(\mathrm{Ocln}^{--}\right)$ manifested extensive histological abnormalities as well as chronic inflammatory responses in intestinal and extra-intestinal organs (41), the genetic deletion of ZO-3 in mice did not cause any signs of developmental abnormalities $(39,42)$.
The integrity of the intestinal TJ proteins is essential for the epithelial impermeability against invading intestinal mucosal pathogens, confining pathogens in the lumen and preventing them to gain access to deeper mucosal layers $(43,44)$. The impaired TJ protein expression at the mucosal surfaces of the intestine leads to the facilitated entry and spread of enteric pathogens (45). Many enteric microbial pathogens, including enteropathogenic and enterohemorrhagic Escherichia coli (EPEC and EHEC, respectively) as well as Helicobacter pylori, secrete virulence factors that target TJ proteins in order to induce pathogenesis (43-45). The Entamoeba histolytica cysteine protease A5 (EhCP-A5) elicited a pro-inflammatory profile, as characterized by increased expression of IFN- $\gamma$, TNF- $\alpha$, and IL13 that correlated with impaired expression of TJ proteins claudin-2, occludin, and ZO-1 (46). The disrupted or the relocalization of $\mathrm{TJ}$ proteins, for example, result in an imbalanced water absorption, an increase in the intra-luminal water content in the intestine and may contribute to the diarrhea observed following the human infections with the attaching and effacing (A/E) EPEC and EHEC $(45,47)$.

Several lines of evidence have indicated that Giardia infection compromises intestinal epithelial barrier integrity in humans as well as in animal models of human giardiasis (48-52). The dysfunctional intestinal epithelial barrier during Giardia infection is characterized by altered expression of TJ proteins (i.e., ZO-1, claudins, occludin), increased intestinal permeability, and reduced transepithelial electrical resistance (TEER) in both murine models of giardiasis as well as in humans $(51,53)$. The disruption of intestinal epithelial TJ proteins is considered a milestone in the pathological changes associated with Giardia infection in vitro and in vivo $(51,53)$. The Giardia infection disruption of intestinal epithelial TJ proteins (i.e., ZO-1) was strain-dependent and could be reversed by using caspase- 3 inhibitors or the pre-treatment with the epidermal growth factor (EGF) (50). Further clinical investigations indicated that the expression of the TJ protein, claudin 1, decreased by $71 \%$ in human subjects with giardiasis as compared with those individuals in the control group (51). It has been postulated that the disruption of the intestinal epithelial TJ proteins during Giardia infection leads to an increased leakage of food antigens through compromised intestinal mucosa into extra-intestinal sites and this may render infected individuals susceptible to allergic reactions commonly observed during human giardiasis (54). Notably, the translocation of commensal bacteria into extra-intestinal sites as a result of Giardia-induced barrier dysfunction correlated with the degradation of TJ proteins occludin and claudin-4 (55). However, it is still unclear how the bacterial translocations into extra-intestinal organs, including mesenteric lymph nodes (MLNs), would contribute to the pathogenesis of human giardiasis. It is yet to be discovered whether different strains of G. duodenalis would cause the differential translocations of bacteria from the intestinal lumen into extra-intestinal organs and whether this potential differential bacterial translocation could account for varied clinical symptoms associated with genetically-diverse $G$. duodenalis strains. 
Several mechanisms have been proposed as to how $G$. duodenalis infection leads to loss of intestinal epithelial barrier integrity during human giardiasis as well as in murine models of human Giardia infection $(50,52)$. The attachment of $G$. duodenalis trophozoites to IECs leads to a contact-dependent alterations in the TJ protein occludin as well as the cellular redistribution of claudin- 1 in fully differentiated Caco-2/TC7 cell monolayers (56). It has been suggested that alterations in the TJ proteins in the brush border (BB) occurred in a contactdependent manner and required the lipid raft membrane of the trophozoite (56). The pre-treatment of the non-transformed human small intestinal epithelial cell line (SCBN) monolayers with EGF (57) or the myosin light chain kinase (MLCK) inhibitor (58), however, significantly prevented the attachment of the live trophozoites to the epithelial monolayers and abolished the parasite-induced disruption of the tight junctional protein ZO-1 (57). The Alerted distribution of TJ proteins, rather than changes in the expression of these proteins, has been proposed as a mechanism underlying the IEC abnormalities observed following Giardia infection (59).

Contact-independent mechanisms also have shown to contribute to the degradation of the TJ proteins and compromised intestinal integrity following Giardia infections; Giardia trophozoites contain a plethora of secreted molecules, including cysteine proteases (CPs), capable of degrading multiple components of the host immune system (60-62). The CPs secreted by Giardia trophozoites are considered emerging virulence factors that are able to degrade TJ proteins (i.e., claudin-1 and -4, occludin, E-cadherin) in IECs and are also capable of degrading chemokines expressed by parasitized IECs $(63,64)$. Recent evidence has suggested that giardipain-1, a cathepsin B-like enzyme, is expressed on the cell surface and flagella of G. duodenalis trophozoites and it can induce apoptosis in IEC-6 epithelial cell monolayers, as evidenced by membrane blebbing and the expression of phosphatidylserine on the surface of parasitized epithelial cell monolayers $(52,60,62)$. Giardipain1 was localized at the epithelial cell-cell junction interface and induced the reorganization and the degradation of occludin and claudin-1 as well as caused decreased TEER in Madin Darby Canine Kidney (MDCK) cell monolayers (52). Consistent with the proteolytic activity of giardipain-1 in degrading the TJ proteins, the pre-treatment with a selective CP inhibitor, E-64, or the siRNA targeting of giardipain-1 gene in $G$. duodenalis trophozoites led to an attenuated proteolytic activity of giardipain-1, as demonstrated by lessened epithelial insult in IEC-6 monolayers. Three major CPs localized in cytoplasm and the endoplasmic reticulum of $G$. duodenalis trophozoites were identified in a Giardia/epithelial cell co-culture setting and further evidence demonstrated that these CPs were capable of proteolyzing or reorganizing multiple $\mathrm{TJ}$ proteins, including claudins and occludin (64). Notably, G. duodenalis trophozoites expressing a variant surface protein, VSP9B10A, were able to induce the loss of cell-cell contact and cell detachment at the sites of the trophozoites attachment (65). The incubation of IEC-6 cell monolayers with conditioned medium obtained from G. duodenalis trophozoites expressing
VSP9B10A/IEC-6 cell monolayers co-culture also induced cytotoxicity, whereas the monoclonal antibody blockade targeting the VSP9B10A protein expressed by trophozoites reversed those cytotoxic effects at the trophozoite/epithelial cell interface $(62,65)$.

Altogether, these findings demonstrate that secreted soluble proteins, including proteases, can immensely contribute to the pathogenesis of $G$. duodenalis infection in vivo. However, it still remains unclear how these parasite-derived CPs contribute to the immunopathology observed during giardiasis and whether vaccine candidates targeting these proteins could protect from parasite-induced immunotherapy. To further understand how TJ protein abnormalities could lead to a malabsorption syndrome (i.e., impaired absorption of electrolytes, water and disaccharidase deficiency) as well as increased intestinal permeability observed during human giardiasis, especially in younger children, further investigations are warranted $(66,67)$.

\section{GIARDIA INDUCES APOPTOSIS IN PARASITIZED IECS}

Apoptotic IECs comprised up to $1.5 \%$ of the total IECs in parasitized human duodenal biopsies following $G$. duodenalis infections, whereas $1 \%$ of the total IECs from duodenal biopsies from healthy controls were apoptotic as determined by a positive terminal transferase uridyl nick end labeling (TUNEL) staining assay (51). Apoptotic IECs, following human G. duodenalis infections, were characterized by chromatin condensation clustering around the nuclear periphery as well as segmentation of the nucleus (51). The Giardia-induced apoptosis in IECs was more evident after infection with non-host specific strains as well as following mixed infections with distinct $G$. duodenalis assemblages (68).

A wide array of mechanisms have been proposed to contribute to apoptosis induced by different genotypes of Giardia parasites in IECs (69). Earlier studies reported a strain-dependent induction of apoptosis in IECs following infection with a single Giardia assemblage or after mixed Giardia infections $(50,68)$. It was shown that the NF and S2 strains of G. duodenalis, but not WB or PB, were able to induce apoptosis in IECs, and these effects were abolished by pretreating human duodenal epithelial monolayers with a caspase3 inhibitor, Z-DEVD-FMK (50). Further studies have indicated the importance of caspases, including caspase $3(50,52,70,71)$ and caspase 9 (72) in mediating Giardia-induced apoptosis in IECs. Giardia infections facilitate apoptosis in IECs by the downregulation of anti-apoptotic proteins, including Bcl-2, and the up-regulation of the pro-apoptotic proteins, including Bax, suggesting a potential contribution of caspase-dependent apoptosis signaling pathways in the induction of pathogenesis during giardiasis $(51,70,73)$.

The production of nitric oxide (NO), and its two major ultimate metabolites (i.e., nitrite and nitrate) by IECs represents another defensive mechanism employed against a 
wide range of lumen-dwelling enteric pathogens at the intestinal epithelium surface $(74,75)$. Giardia parasites interfere with the NO production by IECs through competing over local arginine availability and depriving IECs of arginine is considered a mechanism employed by G. duodenalis to evade NO-mediated killing of the parasite (74). Additionally, this has been suggested as a mechanism by which $G$. duodenalis induces apoptosis in parasitized IECs, since arginine deprivation is known to lead to apoptosis $(74,75)$.

Consistent with the observations that $G$. duodenalis strains differ in their ability to induce pathological changes at the upper intestinal epithelial surface $(50,66,68,76)$, calves infected with assemblage $\mathrm{E}$ neither showed increased rates of apoptotic cells nor did they exhibit any signs of villus shortening as compared with uninfected controls (77). Although the exact mechanisms underlying this discrepancy is still unclear, it is likely that the genetic loci, including triosephosphate isomerase (tpi), glutamate dehydrogenase $(g d h)$ and $\beta$-giardin $(b g)$, commonly used to assign Giardia parasites to specific genotypes/assemblages are not associated with virulence (2).

\section{GIARDIA INFECTION INDUCES CYTOSKELETAL REMODELING IN IECS}

It has been shown that parasitized IECs undergo drastic cytoskeletal remodeling following Giardia infection in vitro and in vivo (76). The expression and the cellular distribution of actin filaments (i.e., F-actin and alpha-actinin) as well as actinbinding proteins (i.e., villin and ezrin) are altered following Giardia infection, leading to compromised intestinal epithelial integrity $(49,76,78)$. The co-incubation of human intestinal epithelial monolayers (i.e., SCBN and Caco 2 cell lines) with live Giardia parasites led to local condensation of F-actin and loss of alpha-actinin in IECs as did the co-culture of monolayers with Giardia lysates or Giardia conditioned medium (49). However, Verapamil, a phenylalkylamine calcium channel blocker, did not alter F-actin reorganization suggesting an extracellular calcium independent-mechanism in the induction of cytoskeletal abnormalities following Giardia infection (49). Further studies demonstrated the significant contribution of host immune responses in the induction of cytoskeletal alterations following Giardia infection in vivo (76). The expression and the cellular distribution of villin and ezrin, the two crucial elements of the actin cytoskeleton of the BB of IECs, underwent major post-transcriptional changes during the clearance phase of G. duodenalis infection in vivo (76). Notably, ezrin and villin were found to be differentially regulated by immune-mediated mechanisms following Giardia infection; while ezrin proteolysis required $\mathrm{CD}^{+} \mathrm{T}$ cells alone, the cleavage of villin required both $\mathrm{CD}^{+}$and $\mathrm{CD}^{+} \mathrm{T}$ cell responses (76). The decreased levels of ezrin phosphorylation as well as increased levels of phosphorylated villin correlated with reduced $\mathrm{BB}$ disaccharidase enzymes (i.e., sucrase, maltase) activity observed during Giardia infection $(66,76)$. Altogether these observations demonstrated that both host and pathogen factors contributed to the cytoskeletal remodeling observed during giardiasis.

\section{GIARDIA INFECTION PROMOTES THE EXPRESSION OF ANTIMICROBIAL PEPTIDES BY PARASITIZED IECS}

As the first line of defense against mucosal pathogens, IECs are equipped with a plethora of defensive mechanisms, including the ability to secret a wide array of antimicrobial peptides (AMPs) (i.e., defensins, trefoil factors) [for a review see ref (79)]. The AMPs are a diverse group of naturally occurring positively charged small molecules and are considered integral components of the innate immune system in a wide range of animals and plants (80). These proteins are crucial against invading mucosa-dwelling microbes, including bacterial, parasitic, and fungal pathogens $(81,82)$. Multiple AMPs, including indolicidin, a 13-residue peptide originally isolated from bovine neutrophils, as well as human defensins possessed antigiardial activity against G. duodenalis trophozoites in vitro (83).

The cytokine IL-22 is shown to promote antimicrobial responses at the mucosal surfaces of the intestine via the regulation of these peptide secretions through interaction with its receptor, IL-22R, which is solely expressed on non-hematopoietic cells, including epithelial cells in the intestine [for a review see ref (84)]. As depicted in Figure 1, we showed that G. duodenalis infection induces IL-22 secretion in a $\mathrm{CD} 4^{+} \mathrm{T}$ cell-dependent manner in a mouse model of the human Giardia infection (66). Giardia infection upregulates the expression of multiple AMPs both in vitro and in vivo (85-87). Caco-2 monolayers incubated with $G$. duodenalis trophozoites promoted the expression of human $\beta$-defensin 2 (HBD-2) and trefoil factor 3 (TFF3) (87). The upregulation of HBD-2 and TFF3 by Caco- 2 monolayers was abolished by pretreatment of $G$. duodenalis with a global CP inhibitor, E-64d, or a cathepsin B CP inhibitor, Ca-074Me (87). Furthermore, Giardia parasite-derived proteases can cleave human defensins (i.e., $\alpha$-HD6 and $\beta$-HD1) in vitro (64), indicating that Giardia parasites likely employ this strategy to evade immune-mediated killing by AMPs in vivo. These observations demonstrate the pivotal roles played by Giardia-derived proteases as contributing factors in the pathogenesis of human giardiasis and exemplify a potential strategy employed by the parasite to survive in vivo and suggests that these AMPs could be devised to boost host's non-immune defense mechanisms against this pathogen.

\section{GIARDIA PARASITES ARE CLOSELY ASSOCIATED WITH THE INTESTINAL EPITHELIUM}

Early studies have shown that G. duodenalis differentially binds to the apical surface and the basolateral membrane of murine cell lines in vitro (88) and trophozoite optimal growth and survival require 


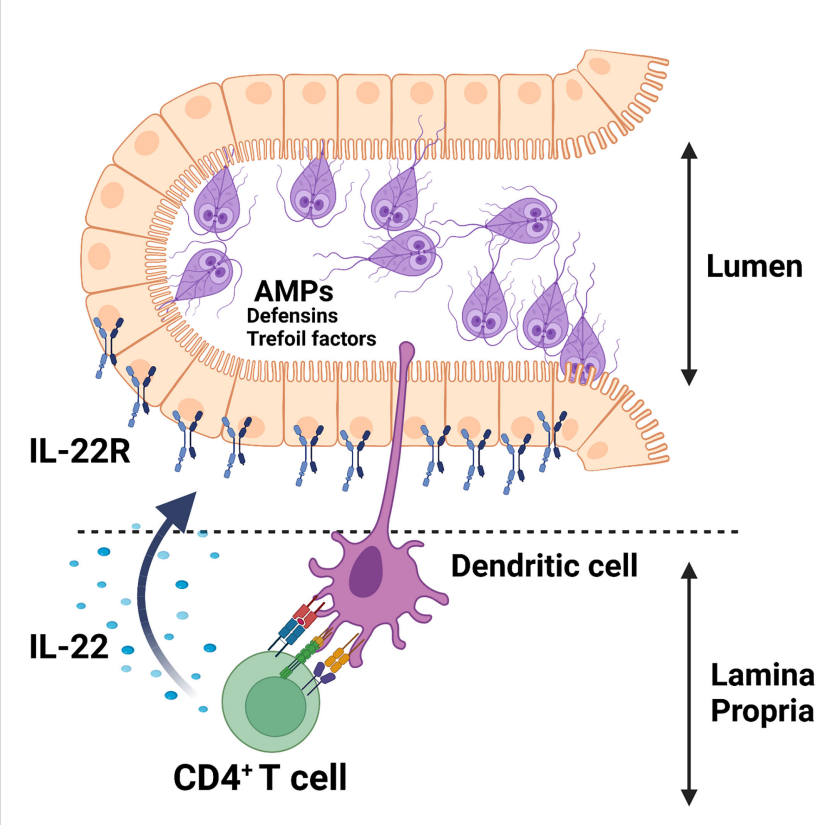

FIGURE 1 | Giardia infection induces the secretion of AMPs (e.g., defensins, trefoil factors) in parasitized IECs likely via an IL-22/IL-22R-mediated mechanism.

intimate interaction with mammalian cells (89). Giardia trophozoites bind to small intestinal IECs with a higher affinity as compared with colonic enterocytes, consistent with the anatomical adaptation/niche in the upper portions of the small intestine (88). Giardia trophozoites adhere to microvilli close to the bases of the villi in the upper portions of the mouse small intestinal epithelium in vivo $(15,90)$. They also have the ability to colonize Peyer's patches throughout the upper portions of the small intestine, but they are not found attaching to microfold cells (also known as M cells) (90). Upon infection, Giardia trophozoites are contained in the lumen and do not invade deeper layers of the intestine. Under certain circumstances (i.e., in immunocompromised individuals), however, Giardia trophozoites become invasive and are spread into intestinal mucosa extending into submucosa layer as well as extra-intestinal sites (91-93). These findings indicate the requirement of an intact immune response in order to contain the parasite within the intestinal lumen.

\section{INTESTINAL EPITHELIUM AS FIRST DEFENSE LAYER AGAINST GIARDIA: ROLE OF INTESTINAL MUCUS LAYER}

The mucosal surface of the intestinal tract represents a main entry point for various microbial pathogens. These microbial pathogens encounter natural innate barriers in the gut, including the mucus layer, in order to prevent potential pathogens or their immunomodulatory components/antigens to reach the underlying epithelium, a process known as non-immune exclusion $(94,95)$. Mucins of the human gastrointestinal tract are highly glycosylated proteins and consist of an apomucin protein backbone (100-500 kDa) joined to oligosaccharides (96). These glycoproteins are secreted by specialized epithelial cell types (i.e., goblet cells) and line the luminal surfaces of the gastrointestinal tract from the oral cavity/oropharynx to rectum (97), and act as the first line of host defense against multiple enteric microbial pathogens, including $G$. duodenalis (61). The mucin binding sites compete with those of underlying intestinal epithelium and limit attachment and the subsequent colonization of the intestinal wall by microbial pathogens (98, 99). Furthermore, the mucus layer of the intestinal tract provides a slimy and viscous physical barrier against ingested pathogens and can substantially limit their access to the underlying intestinal epithelium (100). The gut-dwelling protozoan parasites, including G. duodenalis, encounter natural barriers during intestinal colonization and have developed strategies to streamline this process through evading the recognition by host's non-immune and immune mechanisms (2). The expression of mucins is upregulated following Giardia infection in vitro and in vivo (101-106) and can inhibit the attachment of G. duodenalis trophozoites in vitro most likely through electrostatic repulsion between the trophozoites and the underlying substratum (107). However, not all the components of the mucus possess inhibitory effects on the parasite attachment, since a non-mucin low density, protein-rich fraction of the mucus from the duodenum and ileum of humans or rabbits promoted the attachment and the survival of G. duodenalis trophozoites in a dose-dependent manner in vitro as well as protected trophozoites from being destroyed by the human milk (108-110). While lumen-dwelling protozoan parasites were drastically different in their ability to break down mucins, G. duodenalis produced beta- $\mathrm{N}$-acetylglucosaminidase as well as detectable levels of beta$\mathrm{N}$-acetylgalactosaminidase activity, suggesting the ability of $G$. duodenalis trophozoites to efficiently break down mucins (111). These findings were further confirmed by the observations that animals infected with $G$. duodenalis exhibited a thinner mucus layer and had larger goblet cells (GCs) in greater numbers, accompanied by depleted GCs mucin stores as compared with their uninfected controls $(104,112)$. Consistent with the protective roles played by mucins during giardiasis, mice deficient for mucin 2 gene $\left(\mathrm{Muc2}^{-/-}\right)$showed significantly higher trophozoite burdens in the small intestine and had impaired weight gain as compared with control animals (104). The mucus secretion is regulated by a wide range of immune (i.e., pro-inflammatory cytokines) and non-immune (i.e., diet) factors $(113,114)$. Diets low in fiber facilitate the overgrowth of those bacteria capable of degrading the mucus layer and promotes the subsequent Citrobacter rodentium-induced colitis (115). Consistently, Mongolian gerbils (Meriones unguiculatus) receiving a high-fiber (20\%) diet were more resistant to infection with $G$. duodenalis as compared with those gerbils maintained on a diet with low fiber (5\%) contents (101). The higher mucus secretion in those animals maintained on a highfiber diet was suggested as a factor contributing to the resistance of these animals to G. duodenalis infection (101). These findings reveal an intricate crosstalk between $G$. duodenalis and the 
intestinal mucus layer at the mucosal surfaces of the small intestine. Strategies should be employed to boost non-immune innate mechanisms against intestinal microbial pathogens via restoring eroded mucus layer by promoting the secretion of mucus using fiber-rich diets.

\section{IMMUNE ACTIVATION BY GIARDIA PARASITES AT THE INTESTINAL EPITHELIUM}

Giardia parasites are considered non-invasive to minimally invasive gut pathogens that typically reside on the epithelial surfaces of the upper portions of the small intestine (90). Yet, the adhesion of Giardia parasites to the intestinal epithelium triggers a strong immune response activation, as characterized by an increased influx of immune cell subtypes in the intraepithelial lymphocytes (IELs) as well as in the lamina propria lymphocytes (LPLs) of the small intestine during an early phase of the parasite's colonization $(66,116-121)$. Furthermore, several lines of research have indicated that parasitized IECs secrete a wide array of chemokines and antigiardial factors upon coming into contact with Giardia parasites in vitro and in vivo $(19,74,75,106,122-125)$. The treatment of human colonic cell lines (i.e., Caco-2, HT-29) with the excretory-secretory products of Giardia or whole trophozoites induced the production of pro-inflammatory cytokines TNF- $\alpha$, IL-1 $\beta$, and IL- 8 (also known as CXCL8) by these cells in vitro $(63,125)$. The degradation of CXCL8 via G. duodenalis cathepsin B cysteine proteases attenuates CXCL8induced chemotaxis of human neutrophils $(63,126)$, indicating a potential immune evasion mechanism employed by the parasite to prevent the recruitment of neutrophils via a CXCL8/CXCR1/CXCR2 circuit.

\section{GIARDIA INFECTION PREDISPOSES INFECTED INDIVIDUALS TO DISACCHARIDASE DEFICIENCY}

Disaccharidase enzymes, including sucrase and lactase, are expressed by $\mathrm{BB}$ membrane and IECs in the small intestine. A decrease in the surface area of the small intestine is associated with diminished levels of disaccharidases required for the breakdown of disaccharides into absorbable monosaccharides (127). Sucrase, for example, breaks down sucrose into glucosefructose, whereas lactase and maltase convert lactose and maltose into galactose-glucose and two glucose monomers, respectively. Undigested intact disaccharides can increase the small intestine's osmotic pressure gradients, facilitating the secretion of large quantities of water into the intestinal lumen and leads to intestinal swelling and rapid gastrointestinal transit into the colon (128). Disaccharidase deficiency is observed following various infectious and non-infectious conditions $(66,129,130)$.

As shown in Figure 2, numerous studies have linked disaccharidases deficiency with Giardia infections in both humans and in mouse models of the human disease $(57,117$, 131). Early studies demonstrated that the eradication of the parasite in human subjects infected with $G$. duodenalis led to the disappearance of clinical symptoms and the malabsorption syndrome as well as restored the villi microstructures (132). Among disaccharidases, the lactase deficiency is a common finding in Giardia-infected individuals (133-135), and its deficiency strongly correlates with the severity of mucosal damage in the jejunum and may persist as the lactose intolerance even after the successful chemotherapy (136).

Several mechanisms have been proposed as to how Giardia infection causes disaccharidase deficiency in the small intestine. Gillon et al. found a direct correlation between the impaired expression of disaccharidases and the maximal trophozoite numbers in the jejunum 2 weeks post-infection and thus

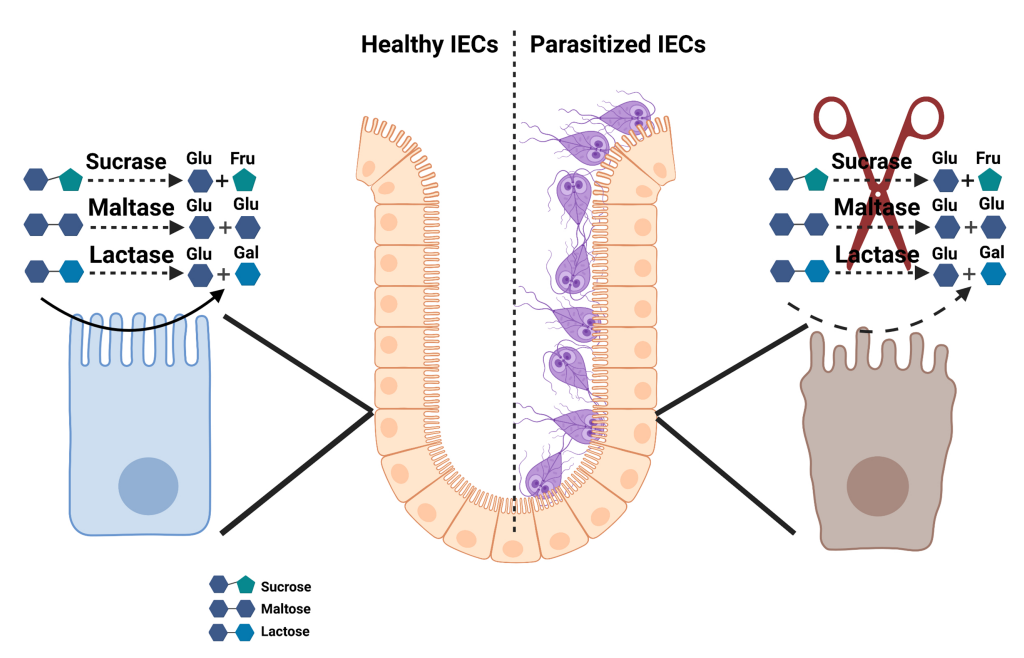

FIGURE 2 | Schematic model of disaccharidase deficiency following infection with Giardia infection in vivo. 
proposed that the parasite's direct effects on the jejunal BB rather than IECs immaturity, accounted for impaired levels of disaccharidase activities in a model of primary G. muris infection (117). In consistent with these observations, it was also proposed that the $G$. duodenalis induction of disaccharidase deficiency was a direct result of the damage to the small intestine epithelial surface rather than bacterial overgrowth, bile aids deconjugation, or immune-mediated host responses (137, 138). However, the IECs immaturity and an increase in the immature/mature IECs ratio have been proposed as a mechanism underlying disaccharidase deficiency, since immature IECs express substantially lower levels of disaccharidases as compared with mature fully-transformed IECs (76). We have demonstrated that $G$. duodenalis infection leads to a facilitated proliferation of IECs, a shift in the immature/mature IECs ratio, and an altered positional distribution/migration of IECs along the crypt-villus axis (CVA) in a primary mouse model of human infection (76). Reduced levels of ezrin phosphorylation as well as enhanced phosphorylation levels of villin correlated with diminished $\mathrm{BB}$ enzyme activity at the peak of $G$. duodenalis infection (76).

The primary G. duodenalis infection in gerbils was associated with ephemeral impairments in disaccharidase activity in the small intestine, whereas the secondary infections in these animals caused even more severe reductions in the disaccharidase levels following infection (139). Notably, the inoculum dose on the rechallenge did not correlate with reduced levels of disaccharidases activity and the presence of viable trophozoites was not required for the induction of severe enzyme deficiency during a secondary G. duodenalis infection $(139,140)$. The disaccharidase deficiency was dependent on the mouse strain and was more evident in those mice susceptible (i.e., $\mathrm{C} 3 \mathrm{H} / \mathrm{HeN}$ ) to $\mathrm{G}$. muris infections as compared with the resistant C57BL/6 strain (141). In an attempt to reveal the contribution of host and parasite factors, including host gender, in the induction of enzyme deficiency during $G$. muris infection, it was observed that male and female mice both had decreased enzyme activities following infection, with males exhibiting persistent reductions in enzyme activity as compared with females and a given strain of Giardia was associated with impaired enzyme activity, whereas as other strains were not (67, $142,143)$. The significantly higher trophozoite numbers in males during a primary infection setting accounted for the genderbased differences in enzyme activity in these animals (142). The gender-biased differences in the microbiome compositions between males and females could potentially explain discrepancies observed in the levels of enzyme activity following Giardia infection, as the microbiome is shown to regulate disaccharidase levels through the activation of $\mathrm{T}$ cell subsets (121). Altogether, these findings highlighted the contribution of host factors, including host's genetic background and gender, in the reduction of $\mathrm{BB}$ enzymes during giardiasis. These observations also emphasized the potential roles played by immune system during giardiasis, especially during secondary infections.

Further investigations have clearly found a more direct link between host's immune status and disaccharidase deficiency in the small intestine following Giardia infection $(66,144,145)$. The BB damage and the subsequent disaccharidase deficiency did not develop in the absence of $\mathrm{T}$ cells in nude mice following $G$. muris infection or in those mice with severe combined immunodeficiency (SCID), lacking both arms of the adaptive immunity $(66,145)$. The adoptive transfer of $\mathrm{CD}^{+} \mathrm{T}$ cells, but not $\mathrm{CD}^{+} \mathrm{T}$ cells, from infected mice into naïve mice led to reduced disaccharidase enzymatic activity in recipients, suggesting that $\mathrm{CD}^{+} \mathrm{T}$ cells are crucial for the induction of $\mathrm{BB}$ abnormalities typically observed during Giardia infection. As such, those mice deficient in $\mathrm{CD}^{+} \mathrm{T}$ cells $\left(\beta_{2} M^{-/-}\right)$cleared G. duodenalis infection similar to their wild-type controls, whereas they did not exhibit defects in disaccharidase activity (66). Based on these findings, it is hypothetically feasible to generate protective immunity against Giardia infections without inducing the $\mathrm{BB}$ damage, including disaccharidase deficiency.

\section{CONCLUSION}

The mucosal surface of the intestinal tract represents a major interface for host-microbe interaction and the main entry route for many microbial pathogens, including Giardia parasites. Intestinal epithelial cells are integral components of an intricate network of immune and non-immune players responsible for the maintenance of the intestinal homeostasis. As a major mucosal surface interfacing between the "self" and the "non-self", the intestinal epithelium participates in host defense against a wide range of lumen-dwelling intestinal pathogens by secreting multiple immune mediators with direct anti-microbial properties. The Giardia attachment to the intestinal epithelium is considered an essential step towards the parasite colonization and the subsequent induction of pathological changes observed during human giardiasis. However, the mechanisms by which Giardia parasites intimately associate with the intestinal epithelium are not fully understood. To this end, a comprehensive understanding of the crosstalk between the intestinal epithelial layer and Giardia parasites will provide insights into the roles contributed by host and parasite factors in the development of immunopathology during human infections and will further provide mechanisms to harness dysregulated immune responses in patients with giardiasis and may offer novel therapeutic targets for the treatment of these patients.

\section{AUTHOR CONTRIBUTIONS}

Conceptualization, writing-original draft, reviewing, and editing: SS-M.

\section{FUNDING}

Research in the Laboratory of Mucosal Immunology is supported by a startup fund (20344-8015) from the Department of 
Biomedical Sciences, School of Medicine and Health Sciences, University of North Dakota (to SS-M), a Dean's Meritorious Pilot Grant, School of Medicine and Health Sciences, University of North Dakota (to SS-M), and by NIH/NIGMSP20GM113123 (to SS-M).

\section{REFERENCES}

1. Adam RD. Biology of Giardia Lamblia. Clin Microbiol Rev (2001) 14:447-75. doi: 10.1128/CMR.14.3.447-475.2001

2. Solaymani-Mohammadi S, Singer SM. Giardia Duodenalis: The DoubleEdged Sword of Immune Responses in Giardiasis. Exp Parasitol (2010) 126:292-7. doi: 10.1016/j.exppara.2010.06.014

3. Yoder JS, Gargano JW, Wallace RM, Beach MJ. Giardiasis SurveillanceUnited States, 2009-2010. MMWR (2012) 2012:61:13-23.

4. Savioli L, Smith H, Thompson A. Giardia and Cryptosporidium Join the 'Neglected Diseases Initiative'. Trends Parasitol (2006) 22:203-8. doi: 10.1016/j.pt.2006.02.015

5. Einarsson E, Ma'ayeh S, Svärd SG. An Up-Date on Giardia and Giardiasis. Curr Opin Microbiol (2016) 34:47-52. doi: 10.1016/j.mib.2016.07.019

6. Thompson RC. Echinococcus, Giardia and Cryptosporidium: Observational Studies Challenging Accepted Dogma. Parasitology (2009) 136:1529-35. doi: $10.1017 / S 0031182009005897$

7. Heyworth MF. Giardia Duodenalis Genetic Assemblages and Hosts. Parasite (2016) 23:13. doi: 10.1051/parasite/2016013

8. Fantinatti M, Bello AR, Fernandes O, Da-Cruz AM. Identification of Giardia Lamblia Assemblage E in Humans Points to a New Anthropozoonotic Cycle. J Infect Dis (2016) 214:1256-9. doi: 10.1093/infdis/jiw361

9. Scalia LA, Fava NM, Soares RM, Limongi JE, da Cunha MJ, Pena IF, et al. Multilocus Genotyping of Giardia Duodenalis in Brazilian Children. Trans R Soc Trop Med Hyg (2016) 110:343-9. doi: 10.1093/trstmh/trw036

10. Abdel-Moein KA, Saeed H. The Zoonotic Potential of Giardia Intestinalis Assemblage E in Rural Settings. Parasitol Res (2016) 115:3197-202. doi: 10.1007/s00436-016-5081-7

11. Zahedi A, Field D, Ryan U. Molecular Typing of Giardia Duodenalis in Humans in Queensland - First Report of Assemblage E. Parasitology (2017) 144:1154-61. doi: 10.1017/S0031182017000439

12. Iwashita H, Sugamoto T, Takemura T, Tokizawa A, Vu TD, Nguyen TH, et al. Molecular Epidemiology of Giardia Spp. In Northern Vietnam: Potential Transmission Between Animals and Humans. Parasite Epidemiol Control (2020) 12:e00193. doi: 10.1016/j.parepi.2020.e00193

13. Garcia-R JC, Ogbuigwe P, Pita AB, Velathanthiri N, Knox MA, Biggs PJ, et al. First Report of Novel Assemblages and Mixed Infections of Giardia Duodenalis in Human Isolates From New Zealand. Acta Trop (2021) 220:105969. doi: 10.1016/j.actatropica.2021.105969

14. Rendtorff RC. The Experimental Transmission of Human Intestinal Protozoan Parasites. II. Giardia Lamblia Cysts Given in Capsules. Am J Hyg (1954) 59:209-20. doi: 10.1093/oxfordjournals.aje.a119634

15. Homan WL, Mank TG. Human Giardiasis: Genotype Linked Differences in Clinical Symptomatology. Int J Parasitol (2001) 31:822-6. doi: 10.1016/ S0020-7519(01)00183-7

16. Istre GR, Dunlop TS, Gaspard GB, Hopkins RS. Waterborne Giardiasis at a Mountain Resort: Evidence for Acquired Immunity. Am J Public Health (1984) 74:602-4. doi: 10.2105/AJPH.74.6.602

17. Isaac-Renton JL, Lewis LF, Ong CS, Nulsen MF. A Second Community Outbreak of Waterborne Giardiasis in Canada and Serological Investigation of Patients. Trans R Soc Trop Med Hyg (1994) 88:395-9. doi: 10.1016/0035-9203(94)90397-2

18. Garzón M, Pereira-da-Silva L, Seixas J, Papoila AL, Alves M, Ferreira F, et al. Association of Enteric Parasitic Infections With Intestinal Inflammation and Permeability in Asymptomatic Infants of São Tomé Island. Pathog Glob Health (2017) 111:116-27. doi: 10.1080/20477724.2017.1299831

19. Kraft MR, Klotz C, Bücker R, Schulzke JD, Aebischer T. Giardia's Epithelial Cell Interaction In Vitro: Mimicking Asymptomatic Infection? Front Cell Infect Microbiol (2017) 7:421. doi: 10.3389/fcimb.2017.00421

\section{ACKNOWLEDGMENTS}

I thank Dr. Emilie Dekrey at the University of North Dakota for comments and useful discussion. Figures $\mathbf{1}$ and $\mathbf{2}$ were generated using Biorender.com.

20. Gilman RH, Brown KH, Visvesvara GS, Mondal G, Greenberg B, Sack RB, et al. Epidemiology and Serology of Giardia Lamblia in a Developing Country: Bangladesh. Trans R Soc Trop Med Hyg (1985) 79:469-73. doi: 10.1016/0035-9203(85)90068-9

21. Mahmud MA, Chappell C, Hossain MM, Habib M, Dupont HL. Risk Factors for Development of First Symptomatic Giardia Infection Among Infants of a Birth Cohort in Rural Egypt. Am J Trop Med Hyg (1995) 53:84-8. doi: 10.4269/ajtmh.1995.53.84

22. Al-Mekhlafi HM, Al-Maktari MT, Jani R, Ahmed A, Anuar TS, Moktar N, et al. Burden of Giardia Duodenalis Infection and Its Adverse Effects on Growth of Schoolchildren in Rural Malaysia. PloS Negl Trop Dis (2013) 7: e2516. doi: 10.1371/journal.pntd.0002516

23. Rogawski ET, Bartelt LA, Platts-Mills JA, Seidman JC, Samie A, Havt A, et al. MAL-ED Network Investigators. Determinants and Impact of Giardia Infection in the First 2 Years of Life in the MAL-ED Birth Cohort. J Pediatr Infect Dis Soc (2017) 6:153-60. doi: 10.1093/jpids/piw082

24. Cowen AE, Campbell CB. Giardiasis-a Cause of Vitamin B12 Malabsorption. Am J Dig Dis (1973) 18:384-90. doi: 10.1007/BF01071987

25. Mahalanabis D, Simpson TW, Chakraborty ML, Ganguli C, Bhattacharjee AK, Mukherjee KL. Malabsorption of Water Miscible Vitamin A in Children With Giardiasis and Ascariasis. Am J Clin Nutr (1979) 32:313-8. doi: 10.1093/ajcn/32.2.313

26. Takahashi M, Katayama Y, Takada H, Hirakawa J, Kuwayama H, Yamaji H, et al. Silent Infection of Giardia Lamblia Causing Bleeding Through Vitamin K Malabsorption. J Gastroenterol Hepatol (2001) 16:1171-2. doi: 10.1046/ j.1440-1746.2001.02414.x

27. Girard C, Dereure O, Blatière V, Guillot B, Bessis D. Vitamin a Deficiency Phrynoderma Associated With Chronic Giardiasis. Pediatr Dermatol (2006) 23:346-9. doi: 10.1111/j.1525-1470.2006.00261.x

28. Quihui-Cota L, Astiazarán-García H, Valencia ME, Morales-Figueroa GG, Lopez-Mata MA, Vazquez Ortiz F. Impact of Giardia Intestinalis on Vitamin A Status in Schoolchildren From Northwest Mexico. Int J Vitam Nutr Res (2008) 78:51-6. doi: 10.1024/0300-9831.78.2.51

29. Astiazaran-Garcia H, Lopez-Teros V, Valencia ME, Vazquez-Ortiz F, Sotelo-Cruz N, Quihui-Cota L. Giardia Lamblia Infection and Its Implications for Vitamin A Liver Stores in School Children. Ann Nutr Metab (2010) 57:228-33. doi: 10.1159/000321682

30. Sutton DL, Kamath KR. Giardiasis With Protein-Losing Enteropathy. J Pediatr Gastroenterol Nutr (1985) 4:56-9. doi: 10.1097/00005176-198502000-00011

31. Korman SH, Bar-Oz B, Mandelberg A, Matoth I. Giardiasis With ProteinLosing Enteropathy: Diagnosis by Fecal Alpha 1-Antitrypsin Determination. J Pediatr Gastroenterol Nutr (1990) 10:249-52. doi: 10.1097/00005176199002000-00019

32. Al-Mekhlafi MS, Azlin M, Nor Aini U, Shaik A, Sa'iah A, Fatmah MS, et al. Giardiasis as a Predictor of Childhood Malnutrition in Orang Asli Children in Malaysia. Trans R Soc Trop Med Hyg (2005) 99:686-891. doi: 10.1016/ j.trstmh.2005.02.006

33. Akkelle BS, Tutar E, Sengul OK, Celikel CA, Ertem D. A Rare Complication of Giardiasis in Children: Protein-Losing Enteropathy. Pediatr Infect Dis $J$ (2018) 37:e345-7. doi: 10.1097/INF.0000000000002025

34. Otani T, Furuse M. Tight Junction Structure and Function Revisited. Trends Cell Biol (2020) 30:805-17. doi: 10.1016/j.tcb.2020.08.004

35. Van Itallie CM, Anderson JM. The Molecular Physiology of Tight Junction Pores. Physiol (Bethesda) (2004) 19:331-8. doi: 10.1152/physiol.00027.2004

36. Van Itallie CM, Anderson JM. Claudins and Epithelial Paracellular Transport. Annu Rev Physiol (2006) 68:403-29. doi: 10.1146/annurev.physiol.68.040104.131404

37. Angelow S, Yu AS. Claudins and Paracellular Transport: An Update. Curr Opin Nephrol Hypertens (2007) 16:459-64. doi: 10.1097/MNH.0b013e32820ac97d 
38. Katsuno T, Umeda K, Matsui T, Hata M, Tamura A, Itoh M, et al. Deficiency of Zonula Occludens-1 Causes Embryonic Lethal Phenotype Associated With Defected Yolk Sac Angiogenesis and Apoptosis of Embryonic Cells. Mol Biol Cell (2008) 19:2465-75. doi: 10.1091/mbc.e07-12-1215

39. Xu J, Kausalya PJ, Phua DC, Ali SM, Hossain Z, Hunziker W. Early Embryonic Lethality of Mice Lacking ZO-2, But Not ZO-3, Reveals Critical and Nonredundant Roles for Individual Zonula Occludens Proteins in Mammalian Development. Mol Cell Biol (2008) 28:1669-78. doi: 10.1128/MCB.00891-07

40. Furuse M, Hata M, Furuse K, Yoshida Y, Haratake A, Sugitani Y, et al. Claudin-Based Tight Junctions Are Crucial for the Mammalian Epidermal Barrier: A Lesson From Claudin-1-Deficient Mice. J Cell Biol (2002) 156:1099-111. doi: 10.1083/jcb.200110122

41. Saitou M, Furuse M, Sasaki H, Schulzke JD, Fromm M, Takano H, et al. Complex Phenotype of Mice Lacking Occludin, a Component of Tight Junction Strands. Mol Biol Cell (2000) 11:4131-42. doi: 10.1091/ mbc.11.12.4131

42. Adachi M, Inoko A, Hata M, Furuse K, Umeda K, Itoh $M$, et al. Normal Establishment of Epithelial Tight Junctions in Mice and Cultured Cells Lacking Expression of ZO-3, a Tight-Junction MAGUK Protein. Mol Cell Biol (2006) 26:9003-15. doi: 10.1128/MCB.01811-05

43. Uotani T, Murakami K, Uchida T, Tanaka S, Nagashima H, Zeng XL, et al. Changes of Tight Junction and Interleukin-8 Expression Using a Human Gastroid Monolayer Model of Helicobacter Pylori Infection. Helicobacter (2019) 24:e12583. doi: 10.1111/hel.12583

44. Lu RY, Yang WX, Hu YJ. The Role of Epithelial Tight Junctions Involved in Pathogen Infections. Mol Biol Rep (2014) 41:6591-610. doi: 10.1007/s11033014-3543-5

45. Ugalde-Silva P, Gonzalez-Lugo O, Navarro-Garcia F. Tight Junction Disruption Induced by Type 3 Secretion System Effectors Injected by Enteropathogenic and Enterohemorrhagic Escherichia Coli. Front Cell Infect Microbiol (2016) 6:87. doi: 10.3389/fcimb.2016.00087

46. Kissoon-Singh V, Moreau F, Trusevych E, Chadee K. Entamoeba Histolytica Exacerbates Epithelial Tight Junction Permeability and Proinflammatory Responses in Muc2(-/-) Mice. Am J Pathol (2013) 182:852-65. doi: 10.1016/ j.ajpath.2012.11.035

47. Guttman JA, Finlay BB. Tight Junctions as Targets of Infectious Agents. Biochim Biophys Acta (2009) 1788:832-41. doi: 10.1016/j.bbamem.2008.10.028

48. Hardin JA, Buret AG, Olson ME, Kimm MH, Gall DG. Mast Cell Hyperplasia and Increased Macromolecular Uptake in an Animal Model of Giardiasis. J Parasitol (1997) 83:908-12. doi: 10.2307/3284287

49. Teoh DA, Kamieniecki D, Pang G, Buret AG. Giardia Lamblia Rearranges FActin and Alpha-Actinin in Human Colonic and Duodenal Monolayers and Reduces Transepithelial Electrical Resistance. J Parasitol (2000) 86:800-6. doi: 10.1645/0022-3395(2000)086[0800:GLRFAA]2.0.CO;2

50. Chin AC, Teoh DA, Scott KG, Meddings JB, Macnaughton WK, Buret AG. Strain-Dependent Induction of Enterocyte Apoptosis by Giardia Lamblia Disrupts Epithelial Barrier Function in a Caspase-3-Dependent Manner. Infect Immun (2002) 70:3673-80. doi: 10.1128/IAI.70.7.3673-3680.2002

51. Troeger H, Epple HJ, Schneider T, Wahnschaffe U, Ullrich R, Burchard GD, et al. Effect of Chronic Giardia Lamblia Infection on Epithelial Transport and Barrier Function in Human Duodenum. Gut (2007) 56:328-35. doi: 10.1136/gut.2006.100198

52. Ortega-Pierres G, Argüello-García R, Laredo-Cisneros MS, Fonseca-Linán R, Gómez-Mondragón M, Inzunza-Arroyo R, et al. Giardipain-1, a Protease Secreted by Giardia Duodenalis Trophozoites, Causes Junctional, Barrier and Apoptotic Damage in Epithelial Cell Monolayers. Int J Parasitol (2018) 48:621-39. doi: 10.1016/j.ijpara.2018.01.006

53. Müller N, von Allmen N. Recent Insights Into the Mucosal Reactions Associated With Giardia Lamblia Infections. Int J Parasitol (2005) 35:1339-47. doi: 10.1016/j.ijpara.2005.07.008

54. Martínez-Girón R. Potential Role of Protozoa and Tight Junctions in the Airway Epithelium Disruption. Clin Respir J (2011) 5:e6. doi: 10.1111/j.1752699X.2010.00215.x

55. Halliez MC, Motta JP, Feener TD, Guérin G, LeGoff L, François A, et al. Giardia Duodenalis Induces Paracellular Bacterial Translocation and Causes Postinfectious Visceral Hypersensitivity. Am J Physiol Gastrointest Liver Physiol (2016) 310:G574-585. doi: 10.1152/ajpgi.00144.2015
56. Humen MA, Pérez PF, Liévin-Le Moal V. Lipid Raft-Dependent Adhesion of Giardia Intestinalis Trophozoites to a Cultured Human Enterocyte-Like Caco-2/TC7 Cell Monolayer Leads to Cytoskeleton-Dependent Functional Injuries. Cell Microbiol (2011) 13:1683-702. doi: 10.1111/j.14625822.2011.01647.x

57. Buret AG, Mitchell K, Muench DG, Scott KG. Giardia Lamblia Disrupts Tight Junctional ZO-1 and Increases Permeability in Non-Transformed Human Small Intestinal Epithelial Monolayers: Effects of Epidermal Growth Factor. Parasitology (2002) 125:11-9. doi: 10.1017/S0031182 002001853

58. Scott KG, Meddings JB, Kirk DR, Lees-Miller SP, Buret AG. Intestinal Infection With Giardia Spp. Reduces Epithelial Barrier Function in a Myosin Light Chain Kinase-Dependent Fashion. Gastroenterology (2002) 123:117990. doi: $10.1053 /$ gast.2002.36002

59. Maia-Brigagão C, Morgado-Díaz JA, De Souza W. Giardia Disrupts the Arrangement of Tight, Adherens and Desmosomal Junction Proteins of Intestinal Cells. Parasitol Int (2012) 61:280-7. doi: 10.1016/j.parint. 2011.11.002

60. Ortega-Pierres MG, Argüello-García R. Giardia Duodenalis: Role of Secreted Molecules as Virulent Factors in the Cytotoxic Effect on Epithelial Cells. Adv Parasitol (2019) 106:129-69. doi: 10.1016/bs.apar.2019.07.003

61. Allain T, Amat CB, Motta JP, Manko A, Buret AG. Interactions of Giardia Sp. With the Intestinal Barrier: Epithelium, Mucus, and Microbiota. Tissue Barriers (2017) 5:e1274354. doi: 10.1080/21688370.2016.1274354

62. Argüello-García R, Ortega-Pierres MG. Giardia Duodenalis Virulence - "To Be, or Not To Be". Curr Trop Med Rep (2021) 1-11. doi: 10.1007/s40475021-00248-z

63. Cotton JA, Bhargava A, Ferraz JG, Yates RM, Beck PL, Buret AG. Giardia Duodenalis Cathepsin B Proteases Degrade Intestinal Epithelial Interleukin8 and Attenuate Interleukin-8-Induced Neutrophil Chemotaxis. Infect Immun (2014) 82:2772-87. doi: 10.1128/IAI.01771-14

64. Liu J, Fu Z, Hellman L, Svärd SG. Cleavage Specificity of Recombinant Giardia Intestinalis Cysteine Proteases: Degradation of Immunoglobulins and Defensins. Mol Biochem Parasitol (2019) 227:29-38. doi: 10.1016/ j.molbiopara.2018.10.004

65. Cabrera-Licona A, Solano-González E, Fonseca-Liñán R, Bazán-Tejeda ML, Argüello-García R, Bermúdez-Cruz RM, et al. Expression and Secretion of the Giardia Duodenalis Variant Surface Protein 9B10A by Transfected Trophozoites Causes Damage to Epithelial Cell Monolayers Mediated by Protease Activity. Exp Parasitol (2017) 179:49-64. doi: 10.1016/ j.exppara.2017.06.006

66. Solaymani-Mohammadi S, Singer SM. Host Immunity and Pathogen Strain Contribute to Intestinal Disaccharidase Impairment Following Gut Infection. J Immunol (2011) 187:3769-75. doi: 10.4049/jimmunol.1100606

67. Cevallos A, Carnaby S, James M, Farthing JG. Small Intestinal Injury in a Neonatal Rat Model of Giardiasis Is Strain Dependent. Gastroenterology (1995) 109:766-73. doi: 10.1016/0016-5085(95)90383-6

68. Koh WH, Geurden T, Paget T, O'Handley R, Steuart RF, Thompson RC, et al. Giardia Duodenalis Assemblage-Specific Induction of Apoptosis and Tight Junction Disruption in Human Intestinal Epithelial Cells: Effects of Mixed Infections. J Parasitol (2013) 99:353-8. doi: 10.1645/GE-3021.1

69. Bartelt LA, Roche J, Kolling G, Bolick D, Noronha F, Naylor C, et al. Persistent G. Lamblia Impairs Growth in a Murine Malnutrition Model. J Clin Invest (2013) 123:2672-84. doi: 10.1172/JCI67294

70. Panaro MA, Cianciulli A, Mitolo V, Mitolo CI, Acquafredda A, Brandonisio O, et al. Caspase-Dependent Apoptosis of the HCT-8 Epithelial Cell Line Induced by the Parasite Giardia Intestinalis. FEMS Immunol Med Microbiol (2007) 51:302-9. doi: 10.1111/j.1574-695X.2007.00304.x

71. Yu LC, Huang CY, Kuo WT, Sayer H, Turner JR, Buret AG. SGLT-1Mediated Glucose Uptake Protects Human Intestinal Epithelial Cells Against Giardia Duodenalis-Induced Apoptosis. Int J Parasitol (2008) 38:923-34. doi: 10.1016/j.ijpara.2007.12.004

72. Liu L, Fang R, Wei Z, Wu J, Li X, Li W. Giardia Duodenalis Induces Apoptosis in Intestinal Epithelial Cells via Reactive Oxygen SpeciesMediated Mitochondrial Pathway In Vitro. Pathogens (2020) 9:693. doi: 10.3390/pathogens9090693

73. Liu L, Wei Z, Fang R, Li X, Li W. Giardia Duodenalis Induces Extrinsic Pathway of Apoptosis in Intestinal Epithelial Cells Through Activation of 
TNFR1 and K63 De-Ubiquitination of RIP1 In Vitro. Microb Pathog (2020) 149:104315. doi: 10.1016/j.micpath.2020.104315

74. Eckmann L, Laurent F, Langford TD, Hetsko ML, Smith JR, Kagnoff MF, et al. Nitric Oxide Production by Human Intestinal Epithelial Cells and Competition for Arginine as Potential Determinants of Host Defense Against the Lumen-Dwelling Pathogen Giardia Lamblia. J Immunol (2000) 164:1478-87. doi: 10.4049/jimmunol.164.3.1478

75. Eckmann L. Mucosal Defences Against Giardia. Parasite Immunol (2003) 25:259-70. doi: 10.1046/j.1365-3024.2003.00634.x

76. Solaymani-Mohammadi S, Singer SM. Regulation of Intestinal Epithelial Cell Cytoskeletal Remodeling by Cellular Immunity Following Gut Infection. Mucosal Immunol (2013) 6:369-78. doi: 10.1038/mi.2012.80

77. Barigye R, Dyer NW, Newell TK, Khaitsa ML, Trout JM, Santin M, et al. Molecular and Immunohistochemical Detection of Assemblage E, Giardia Duodenalis in Scouring North Dakota Calves. Vet Parasitol (2008) 157:196202. doi: 10.1016/j.vetpar.2008.07.033

78. Bhargava A, Cotton JA, Dixon BR, Gedamu L, Yates RM, Buret AG. Giardia Duodenalis Surface Cysteine Proteases Induce Cleavage of the Intestinal Epithelial Cytoskeletal Protein Villin via Myosin Light Chain Kinase. PloS One (2015) 10:e0136102. doi: 10.1371/journal.pone.0136102

79. Larsen SB, Cowley CJ, Fuchs E. Epithelial Cells: Liaisons of Immunity. Curr Opin Immunol (2020) 62:45-53. doi: 10.1016/j.coi.2019.11.004

80. López Cascales JJ, Zenak S, García de la Torre J, Lezama OG, Garro A, Enriz RD. Small Cationic Peptides: Influence of Charge on Their Antimicrobial Activity. ACS Omega (2018) 3:5390-8. doi: 10.1021/acsomega.8b00293

81. Iimura M, Gallo RL, Hase K, Miyamoto Y, Eckmann L, Kagnoff MF. Cathelicidin Mediates Innate Intestinal Defense Against Colonization With Epithelial Adherent Bacterial Pathogens. J Immunol (2005) 174:4901-7. doi: 10.4049/jimmunol.174.8.4901

82. van Eijk M, Boerefijn S, Cen L, Rosa M, Morren MJH, van der Ent CK, et al. Cathelicidin-Inspired Antimicrobial Peptides as Novel Antifungal Compounds. Med Mycol (2020) 58:1073-84. doi: 10.1093/mmy/myaa014

83. Aley SB, Zimmerman M, Hetsko M, Selsted ME, Gillin FD. Killing of Giardia Lamblia by Cryptdins and Cationic Neutrophil Peptides. Infect Immun (1994) 62:5397-403. doi: 10.1128/iai.62.12.5397-5403.1994

84. Sonnenberg GF, Fouser LA, Artis D. Functional Biology of the IL-22-IL-22r Pathway in Regulating Immunity and Inflammation at Barrier Surfaces. $A d v$ Immunol (2010) 107:1-29. doi: 10.1016/B978-0-12-381300-8.00001-0

85. Paerewijck O, Maertens B, Dreesen L, Van Meulder F, Peelaers I, Ratman D, et al. Interleukin-17 Receptor A (IL-17RA) as a Central Regulator of the Protective Immune Response Against Giardia. Sci Rep (2017) 7:8520. doi: 10.1038/s41598-017-08590-x

86. Manko A, Motta JP, Cotton JA, Feener T, Oyeyemi A, Vallance BA, et al. Giardia Co-Infection Promotes the Secretion of Antimicrobial Peptides Beta-Defensin 2 and Trefoil Factor 3 and Attenuates Attaching and Effacing Bacteria-Induced Intestinal Disease. PloS One (2017) 12:e0178647. doi: 10.1371/journal.pone.0178647

87. Manko-Prykhoda A, Allain T, Motta JP, Cotton JA, Feener T, Oyeyemi A, et al. Giardia Spp. Promote the Production of Antimicrobial Peptides and Attenuate Disease Severity Induced by Attaching and Effacing Enteropathogens via the Induction of the NLRP3 Inflammasome. I. Nt J Parasitol (2020) 50:263-75. doi: 10.1016/j.ijpara.2019.12.011

88. Inge PM, Edson CM, Farthing MJ. Attachment of Giardia Lamblia to Rat Intestinal Epithelial Cells. Gut (1988) 29:795-801. doi: 10.1136/gut.29.6.795

89. Nash TE. Long-Term Culture of Giardia Lamblia in Cell Culture Medium Requires Intimate Association With Viable Mammalian Cells. Infect Immun (2019) 87:e00639-19. doi: 10.1128/IAI.00639-19

90. Owen RL, Nemanic PC, Stevens DP. Ultrastructural Observations on Giardiasis in a Murine Model. I. Intestinal Distribution, Attachment, and Relationship to the Immune System of Giardia Muris. Gastroenterology (1979) 76:757-69. doi: 10.1016/S0016-5085(79)80176-6

91. Brandborg LL, Tankersley CB, Gottieb S, Barancik M, Sartor VE. Histological Demonstration of Mucosal Invasion by Giardia Lamblia in Man. Gastroenterology (1967) 52:143-50. doi: 10.1016/S0016-5085(67) 80001-5

92. Saha TK, Ghosh TK. Invasion of Small Intestinal Mucosa by Giardia Lamblia in Man. Gastroenterology (1977) 72:402-5. doi: 10.1016/S00165085(77) $80247-3$
93. Reynoso-Robles R, Ponce-Macotela M, Rosas-López LE, Ramos-Morales A, Martínez-Gordillo MN, González-Maciel A. The Invasive Potential of Giardia Intestinalis in an In Vivo Model. Sci Rep (2015) 5:15168. doi: 10.1038/srep15168

94. Dharmani P, Srivastava V, Kissoon-Singh V, Chadee K. Role of Intestinal Mucins in Innate Host Defense Mechanisms Against Pathogens. J Innate Immun (2009) 1:123-35. doi: 10.1159/000163037

95. Solaymani-Mohammadi S, Petri WA Jr. Intestinal Invasion by Entamoeba Histolytica. Subcell Biochem (2008) 47:221-32. doi: 10.1007/978-0-38778267-6_18

96. Bansil R, Turner BS. The Biology of Mucus: Composition, Synthesis and Organization. Adv Drug Deliv Rev (2018) 124:3-15. doi: 10.1016/j.addr. 2017.09.023

97. Lamont JT. Mucus: The Front Line of Intestinal Mucosal Defense. Ann NY Acad Sci (1992) 664:190-201. doi: 10.1111/j.1749-6632.1992.tb39760.x

98. Vimal D, Khullar M, Gupta S, Ganguly N. Intestinal Mucins: The Binding Sites for Salmonella Typhimurium. Mol Cell Biochem (2000) 204:107-17. doi: 10.1023/A:1007015312036

99. Linden SK, Sutton P, Karlsson NG, Korolik V, McGuckin MA. Mucins in the Mucosal Barrier to Infection. Mucosal Immunol (2008) 1:183-97. doi: $10.1038 / \mathrm{mi} .2008 .5$

100. McGuckin MA, Linden SK, Sutton P, Florin TF. Mucin Dynamics and Enteric Pathogens. Nat Rev Microbiol (2011) 9:265-78. doi: 10.1038/ nrmicro2538

101. Leitch GJ, Visvesvara GS, Wahlquist SP, Harmon CT. Dietary Fiber and Giardiasis: Dietary Fiber Reduces Rate of Intestinal Infection by Giardia Lamblia in the Gerbil. Am J Trop Med Hyg (1989) 41:512-20. doi: 10.4269/ ajtmh.1989.41.512

102. Macechko PT, van Keulen H, Jarroll EL, Mulgrew T, Gurien A, Erlandsen SL. Detection of Giardia Trophozoites in Archival Pathology Specimens of Human Small Intestine. Microsc Microanal (1998) 4:397-403. doi: $10.1017 /$ S1431927698980370

103. Ventura LL, Oliveira DR, Viana JC, Santos JF, Caliari MV, Gomes MA. Impact of Protein Malnutrition on Histological Parameters of Experimentally Infected Animals With Giardia Lamblia. Exp Parasitol (2013) 133:391-5. doi: 10.1016/j.exppara.2013.01.007

104. Amat CB, Motta JP, Fekete E, Moreau F, Chadee K, Buret AG. Cysteine Protease Dependent Mucous Disruptions and Differential Mucin Gene Expression in Giardia Duodenalis Infection. Am J Pathol (2017) 187:248698. doi: 10.1016/j.ajpath.2017.07.009

105. Araújo NS, Mundim MJ, Gomes MA, Amorim RM, Viana JC, Queiroz RP, et al. Giardia Duodenalis: Pathological Alterations in Gerbils, Meriones Unguiculatus, Infected With Different Dosages of Trophozoites. Exp Parasitol (2008) 118:449-57. doi: 10.1016/j.exppara.2007.10.007

106. Ma'ayeh SY, Knörr L, Sköld K, Garnham A, Ansell BRE, Jex AR, et al. Responses of the Differentiated Intestinal Epithelial Cell Line Caco-2 to Infection With the Giardia Intestinalis GS Isolate. Front Cell Infect Microbiol (2018) 8:244. doi: 10.3389/fcimb.2018.00244

107. Roskens H, Erlandsen SL. Inhibition of In Vitro Attachment of Giardia Trophozoites by Mucin. J Parasitol (2002) 88:869-73. doi: 10.1645/00223395(2002)088[0869:IOIVAO]2.0.CO;2

108. Zenian AJ, Gillin FD. Intestinal Mucus Protects Giardia Lamblia From Killing by Human Milk. J Protozool (1987) 34:22-6. doi: 10.1111/j.15507408.1987.tb03124.x

109. Zenian A, Gillin FD. Interactions of Giardia Lamblia With Human Intestinal Mucus: Enhancement of Trophozoite Attachment to Glass. J Protozool (1985) 32:664-8. doi: 10.1111/j.1550-7408.1985.tb03098.x

110. Gault MJ, Gillin FD, Zenian AJ. Giardia Lamblia: Stimulation of Growth by Human Intestinal Mucus and Epithelial Cells in Serum Free Medium. Exp Parasitol (1987) 64:29-37. doi: 10.1016/0014-4894(87)90005-1

111. Connaris S, Greenwell P. Glycosidases in Mucin-Dwelling Protozoans. Glycoconj J (1997) 14:879-82. doi: 10.1023/A:1018554408558

112. Ponce-Macotela M, González-Maciel A, Reynoso-Robles R, MartínezGordillo MN. Goblet Cells: Are They an Unspecific Barrier Against Giardia Intestinalis or a Gate? Parasitol Res (2008) 102:509-13. doi: 10.1007/s00436-007-0790-6

113. Vahouny GV, Le T, Ifrim I, Satchithanandam S, Cassidy MM. Stimulation of Intestinal Cytokinetics and Mucin Turnover in Rats Fed Wheat Bran or Cellulose. Am J Clin Nutr (1985) 41:895-900. doi: 10.1093/ajcn/41.5.895 
114. Cornick S, Tawiah A, Chadee K. Roles and Regulation of the Mucus Barrier in the Gut. Tissue Barriers (2015) 3:e982426. doi: 10.4161/21688370. 2014.982426

115. Desai MS, Seekatz AM, Koropatkin NM, Kamada N, Hickey CA, Wolter M, et al. A Dietary Fiber-Deprived Gut Microbiota Degrades the Colonic Mucus Barrier and Enhances Pathogen Susceptibility. Cell (2016) 167:13391353.e21. doi: 10.1016/j.cell.2016.10.043

116. Babaei Z, Malihi N, Zia-Ali N, Sharifi I, Mohammadi MA, Kagnoff MF, et al. Adaptive Immune Response in Symptomatic and Asymptomatic Enteric Protozoal Infection: Evidence for a Determining Role of Parasite Genetic Heterogeneity in Host Immunity to Human Giardiasis. Microbes Infect (2016) 18:687-95. doi: 10.1016/j.micinf.2016.06.009

117. Gillon J, Al Thamery D, Ferguson A. Features of Small Intestinal Pathology (Epithelial Cell Kinetics, Intraepithelial Lymphocytes, Disaccharidases) in a Primary Giardia Muris Infection. Gut (1982) 23:498-506. doi: 10.1136/ gut.23.6.498

118. Vinayak VK, Khanna R, Kum K. Kinetics of Intraepithelium and Lamina Propria Lymphocyte Responses During Giardia Lamblia Infection in Mice. Microb Pathog (1991) 10:343-50. doi: 10.1016/0882-4010(91)90079-P

119. Hanevik K, Kristoffersen E, Svard S, Bruserud O, Ringqvist E, Sørnes S, et al. Human Cellular Immune Response Against Giardia Lamblia 5 Years After Acute Giardiasis. J Infect Dis (2011) 204:1779-86. doi: 10.1093/infdis/jir639

120. Saghaug CS, Sørnes S, Peirasmaki D, Svärd S, Langeland N, Hanevik K. Human Memory CD4 ${ }^{+} \mathrm{T}$ Cell Immune Responses Against Giardia Lamblia. Clin Vaccine Immunol (2015) 23:11-8. doi: 10.1128/CVI.00419-15

121. Keselman A, Li E, Maloney J, Singer SM. The Microbiota Contributes to $\mathrm{CD}^{+} \mathrm{T}$ Cell Activation and Nutrient Malabsorption Following Intestinal Infection With Giardia Duodenalis. Infect Immun (2016) 84:2853-60. doi: 10.1128/IAI.00348-16

122. Roxström-Lindquist K, Ringqvist E, Palm D, Svärd S. Giardia LambliaInduced Changes in Gene Expression in Differentiated Caco-2 Human Intestinal Epithelial Cells. Infect Immun (2005) 73:8204-8. doi: 10.1128/ IAI.73.12.8204-8208.2005

123. Stadelmann B, Merino MC, Persson L, Svärd SG. Arginine Consumption by the Intestinal Parasite Giardia Intestinalis Reduces Proliferation of Intestinal Epithelial Cells. PloS One (2012) 7:e45325. doi: 10.1371/journal.pone.0045325

124. Fisher BS, Estraño CE, Cole JA. Modeling Long-Term Host Cell-Giardia Lamblia Interactions in an In Vitro Co-Culture System. PloS One (2013) 8: e81104. doi: 10.1371/journal.pone.0081104

125. Lee HY, Hyung S, Lee NY, Yong TS, Han SH, Park SJ. Excretory-Secretory Products of Giardia Lamblia Induce Interleukin-8 Production in Human Colonic Cells via Activation of P38, ERK1/2, NF-Kb and AP-1. Parasite Immunol (2012) 34:183-98. doi: 10.1111/j.1365-3024.2012.01354.x

126. Cotton JA, Motta JP, Schenck LP, Hirota SA, Beck PL, Buret AG. Giardia Duodenalis Infection Reduces Granulocyte Infiltration in an In Vivo Model of Bacterial Toxin-Induced Colitis and Attenuates Inflammation in Human Intestinal Tissue. PloS One (2014) 9:e109087. doi: 10.1371/journal.pone.0109087

127. Farthing MJ. The Molecular Pathogenesis of Giardiasis. J Pediatr Gastroenterol Nutr (1997) 24:79-88. doi: 10.1097/00005176-19970100000018

128. Gericke B, Amiri M, Naim HY. The Multiple Roles of Sucrase-Isomaltase in the Intestinal Physiology. Mol Cell Pediatr (2016) 3:2. doi: 10.1186/s40348016-0033-y

129. Taylor C, Hodgson K, Sharpstone D, Sigthorsson G, Coutts M, Sherwood R, et al. The Prevalence and Severity of Intestinal Disaccharidase Deficiency in Human Immunodeficiency Virus-Infected Subjects. Scand J Gastroenterol (2000) 35:599-606. doi: 10.1080/003655200750023552

130. Mones RL, Yankah A, Duelfer D, Bustami R, Mercer G. Disaccharidase Deficiency in Pediatric Patients With Celiac Disease and Intact Villi. Scand J Gastroenterol (2011) 46:1429-34. doi: 10.3109/00365521.2011.619276

131. Jennings W, Rowland R, Hecker R, Gibson GE, Fitch RJ, Reid DP. The Significance of Lowered Jejunal Disaccharidase Levels. Aust N Z J Med (1976) 6:556-60. doi: 10.1111/j.1445-5994.1976.tb03994.x

132. Ochs HD, Ament ME, Davis SD. Structure and Function of the Gastrointestinal Tract in Primary Immunodeficiency Syndromes (IDS) and in Granulocyte Dysfunction. Birth Defects Orig Artic Ser (1975) 11:199-207.

133. Judd R, Deckelbaum RJ, Weizman Z, Granot E, Ron N, Okon E. Giardiasis in Childhood: Poor Clinical and Histological Correlations. Isr J Med Sci (1983) 19:818-23.

134. Singh KD, Bhasin DK, Rana SV, Vaiphei K, Katyal R, Vinayak VK, et al. Effect of Giardia Lamblia on Duodenal Disaccharidase Levels in Humans. Trop Gastroenterol (2000) 21:174-6.

135. Ish-Horowicz M, Korman SH, Shapiro M, Har-Even U, Tamir I, Strauss N, et al. Asymptomatic Giardiasis in Children. Pediatr Infect Dis J (1989) 8:7739. doi: 10.1097/00006454-198911000-00009

136. Gendrel D, Richard-Lenoble D, Kombila M, Dupont C, Moreno JL, Gendrel $\mathrm{C}$, et al. Influence of Intestinal Parasitism on Lactose Absorption in WellNourished African Children. Am J Trop Med Hyg (1992) 46:137-40. doi: 10.4269/ajtmh.1992.46.137

137. Anand BS, Chaudhary R, Jyothi A, Yadev RS, Baveja UK. Experimental Examination of the Direct Damaging Effects of Giardia Lamblia on Intestinal Mucosal Scrapings of Mice. Trans R Soc Trop Med Hyg (1985) 79:613-7. doi: 10.1016/0035-9203(85)90167-1

138. Khanna R, Vinayak VK, Mehta S, KumKum, Nain CK. Giardia Lamblia Infection in Immunosuppressed Animals Causes Severe Alterations to Brush Border Membrane Enzymes. Dig Dis Sci (1988) 33:1147-52. doi: 10.1007/ BF01535792

139. Belosevic M, Faubert GM, MacLean JD. Disaccharidase Activity in the Small Intestine of Gerbils (Meriones Unguiculatus) During Primary and Challenge Infections With Giardia Lamblia. Gut (1989) 30:1213-9. doi: 10.1136/ gut.30.9.1213

140. Mohammed SR, Faubert GM. Disaccharidase Deficiencies in Mongolian Gerbils (Meriones Unguiculatus) Protected Against Giardia Lamblia. Parasitol Res (1995) 81:582-90. doi: 10.1007/BF00932025

141. Daniels CW, Belosevic M. Disaccharidase Activity in the Small Intestine of Susceptible and Resistant Mice After Primary and Challenge Infections With Giardia Muris. Am J Trop Med Hyg (1992) 46:382-90. doi: 10.4269/ ajtmh.1992.46.382

142. Daniels CW, Belosevic M. Disaccharidase Activity in Male and Female C57BL/6 Mice Infected With Giardia Muris. Parasitol Res (1995) 81:143-7. doi: 10.1007/BF00931620

143. Bénéré E, Van Assche T, Van Ginneken C, Peulen O, Cos P, Maes L. Intestinal Growth and Pathology of Giardia Duodenalis Assemblage Subtype A(I), A(II), B and E in the Gerbil Model. Parasitology (2012) 139:424-33. doi: 10.1017/S0031182011002137

144. Scott KG, Logan MR, Klammer GM, Teoh DA, Buret AG. Jejunal Brush Border Microvillous Alterations in Giardia Muris-Infected Mice: Role of T Lymphocytes and Interleukin-6. Infect Immun (2000) 68:3412-8. doi: 10.1128/IAI.68.6.3412-3418.2000

145. Scott KG, Yu LC, Buret AG. Role of $\mathrm{CD}^{+}$and $\mathrm{CD} 4^{+} \mathrm{T}$ Lymphocytes in Jejunal Mucosal Injury During Murine Giardiasis. Infect Immun (2004) 72:3536-42. doi: 10.1128/IAI.72.6.3536-3542.2004

Conflict of Interest: The author declares that the research was conducted in the absence of any commercial or financial relationships that could be construed as a potential conflict of interest.

Publisher's Note: All claims expressed in this article are solely those of the authors and do not necessarily represent those of their affiliated organizations, or those of the publisher, the editors and the reviewers. Any product that may be evaluated in this article, or claim that may be made by its manufacturer, is not guaranteed or endorsed by the publisher.

Copyright (c) 2022 Solaymani-Mohammadi. This is an open-access article distributed under the terms of the Creative Commons Attribution License (CC BY). The use, distribution or reproduction in other forums is permitted, provided the original author(s) and the copyright owner(s) are credited and that the original publication in this journal is cited, in accordance with accepted academic practice. No use, distribution or reproduction is permitted which does not comply with these terms. 